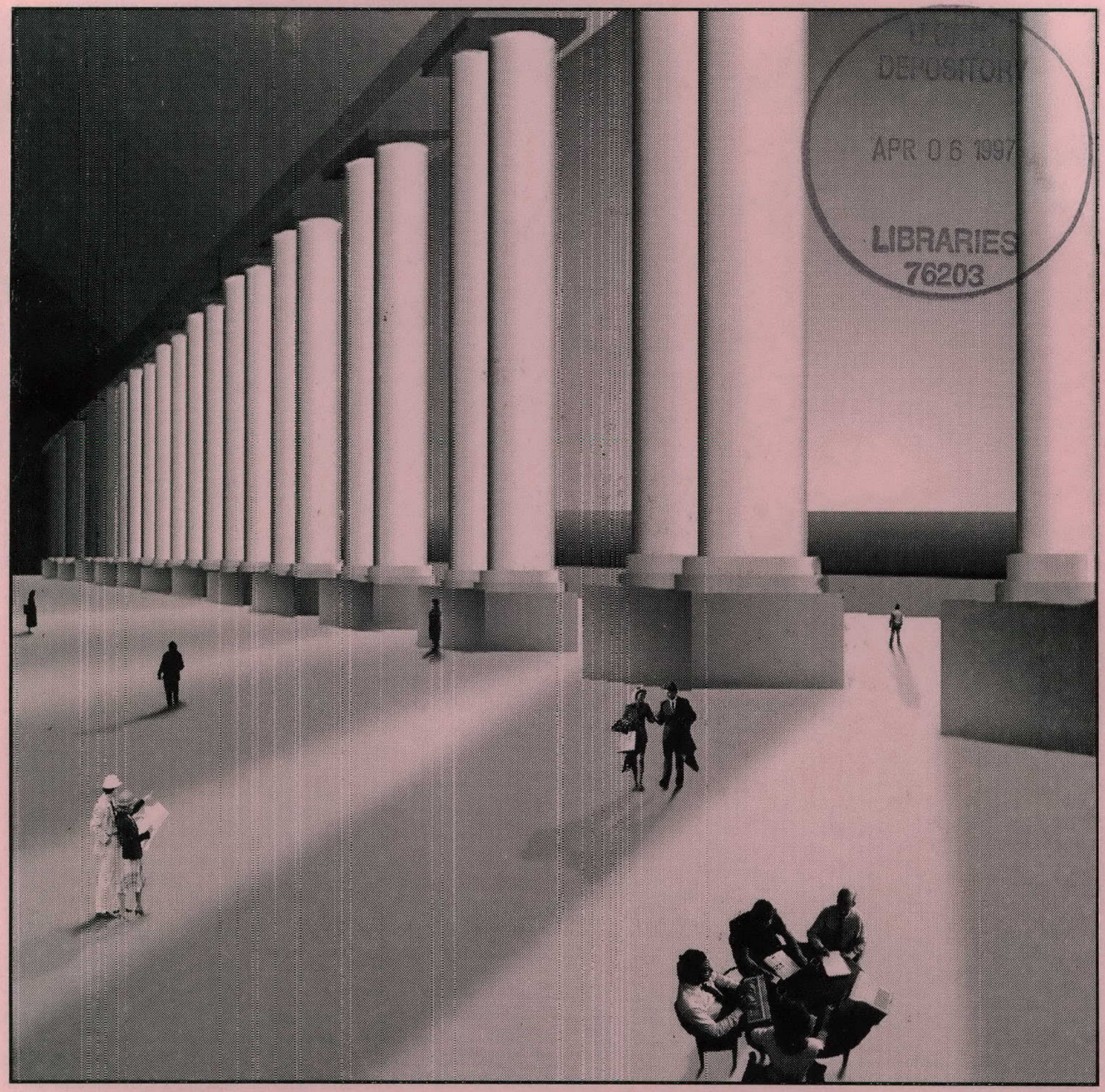

\title{
The Coming Downsizing in Real Estate: Implications of Technology
}

John S. Baen and Randall S. Guttery

Working Paper 1143 


\section{Real Estate Center}

\section{Director}

\section{Dr. R. Malcolm Richards}

The Real Estate Center was created in 1971 by the Texas Legislature and placed at Texas A\&M University.

The Center conducts a comprehensive program of research and education to meet the needs of many audiences, including the real estate industry, instructors and the general public.

A catalog describing hundreds of publications and computer programs is free for the asking. Write the Real Estate Center, Texas A\&M University, College Station, Texas 77843-2115 or telephone 1-800-244-2144. Timely real estate information also is available on the Internet at http://recenter.tamu.edu.

\section{Advisory Committee}

John P. Schneider, Jr., Austin, chairman; Gloria Van Zandt, Arlington, vice chairman; Michael M. Beal, College Station; Conrad Bering, Jr., Houston; Melissa C. Cigarroa, Laredo; Dr. Donald S. Longworth, Lubbock; Carlos Madrid, Jr., San Antonio; Andrea Lopes Moore, Houston; Kay Moore, Big Spring; and Pete Cantu, Sr., San Antonio, ex-officio representing the Texas Real Estate Commission.

(C) 1996, Real Estate Center. All rights reserved.

\section{Solutions Through Research}




\section{Contents}

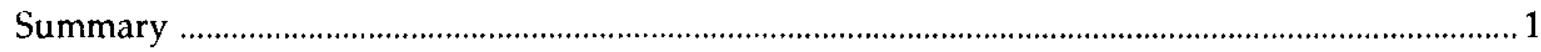

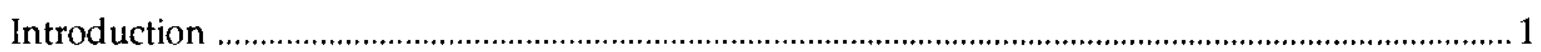

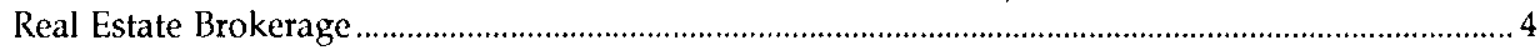

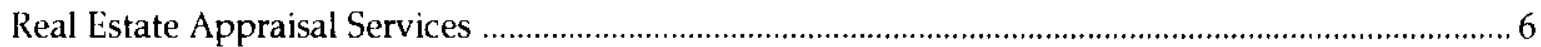

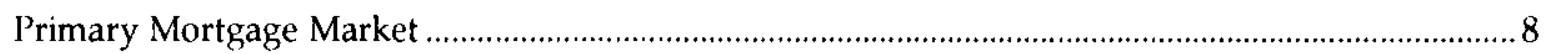

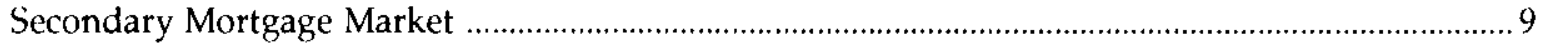

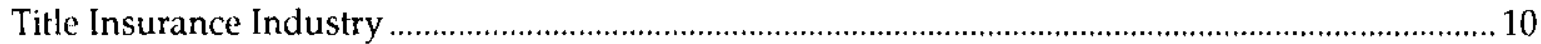

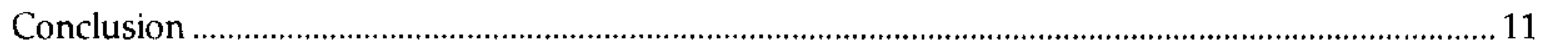


, 


\section{Summary}

Consumer and business computing is growing at an explosive rate. Databases that may be merged to create user-friendly real estate related market information and services also are expanding. Reduction in traditional personal customer services and the ease of collection, assimilation and processing of information have major implications for the real estate industry and future employment prospects. The research reported here collects employment trends by standard industrial codes and other sources and assesses rapid changes in real estate brokerage, finance, appraisal, leasing and title insurance resulting from computer and technology capabilities. Findings suggest that the number of real estate participants employed currently will decline significantly because of increased efficiencies. A wealth transfer is anticipated-to homebuyers and sellers from licensed agents, lenders, appraisers, attorneys and loan servicers.

\section{Introduction}

$\mathrm{R}$ eal estate agents, appraisers, mortgage loan originators and title companies exist, in part, because of inefficiencies in the traditional real estate market. The lack of information between buyers and sellers of property and/or between mortgage borrowers and lenders, combined with the requirement of independent estimations of value and confirmation of valid land title, ensure employment for millions of Americans (Figures 1-5). For example, from 1980 through 1993, an average of 700,000 people per year were employed full-time as real estate agents or managers, nearly two million worked in the banking industry each year and more than 100,000 were subdividers, developers or both.

Two changes are revolutionizing the real estate industry: the current explosive growth of both consumer and real estate services business computing and the expanding databases containing previously unconsolidated and often unavailable market information. Instantaneous access and easily usable decision-making data are a reality for all participants in real estate transactions. The real estate property and mortgage markets, together with supporting professions and service providers, are in the throes of a paradigm shift. Significant changes in employment and compensation levels-as the prevailing, comparatively high transaction costs in the sale or purchase of real estate are reducedare major implications.

\section{Current Internet Real Estate Customer Profile}

Dun and Bradstreet (1996) estimate that 17 percent of North Americans age 16 or older ( 37 million people) have Internet access, and 65 percent of them used the Internet during the first quarter of 1996. The demographic profile of Internet users reveals that:

- Sixty-six percent of Internet users are male.

- Twenty-five percent of web users have a household annual income exceeding $\$ 80,000$, while only 10 percent of the general population earns such income.

- Fifty percent of web users, compared with 27 percent of the population, consider themselves to be in professional or managerial occupations.

- Sixty-four percent of web users have at least one college degree, compared with 29 percent of the total population.

- Users average 5.5 hours per week on the Internet, compared with 2.5 hours on other on-line services.

AT\&T announced in March 1996 its intent to provide customers with five hours per month of free Internet access and unlimited access 
Figure 1. Real Estate Agents and Managers

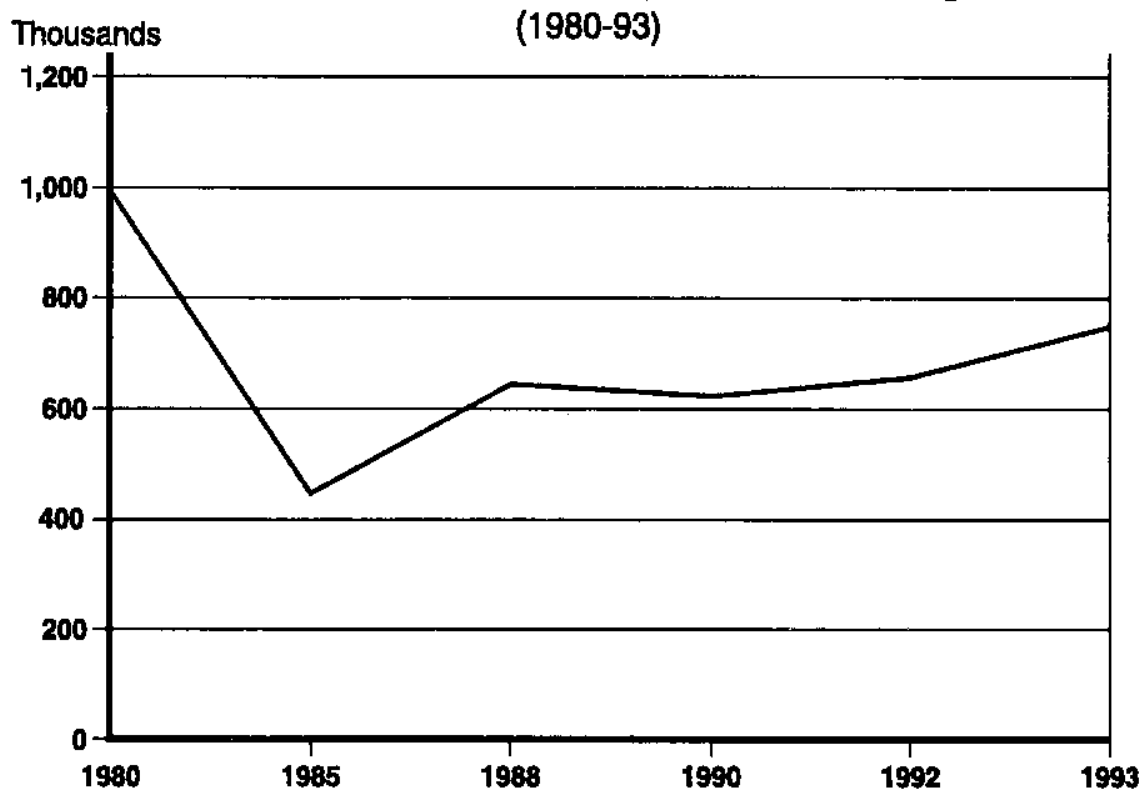

Source: U.S. County Business Patterns

thereafter for $\$ 19.95$ per month. This creates new links between the World Wide Web (WWW) and millions of AT\& $T^{\prime}$ 's customers. This is only the beginning trend of increasing availability and falling cost for both telephone service (e.g., cellular phones) and the Internet, thus expanding across all socioeconomic classes.
The implications for the real estate industry are monumental. In January 1995, approximately 100 real estate web sites offered real estate for sale. By year-end, more than 4,000 real estate related web sites came on-line, expanding to more than 8,000 today. A sample of 36 randomly chosen home pages and a brief overview of their services are

Figure 2.

Bank Employment: Commercial and Savings Institutions

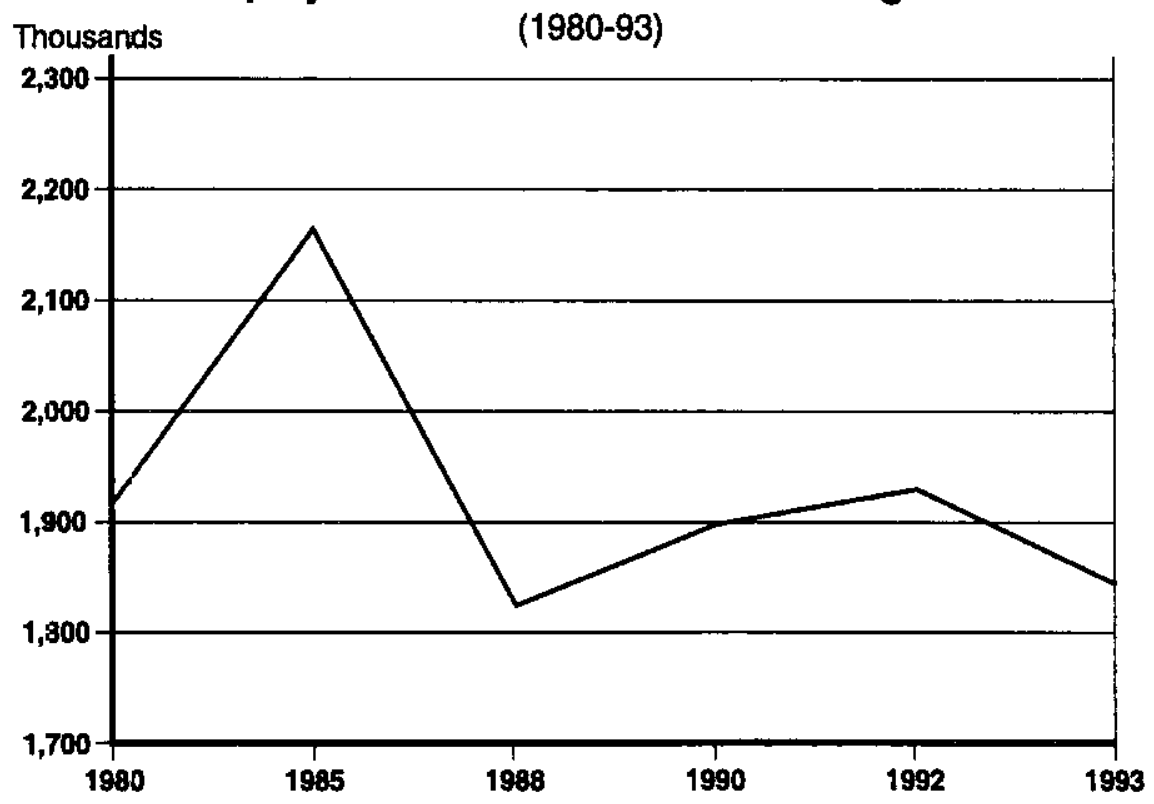

Source: U.S. County Business Patterns 
Figure 3.

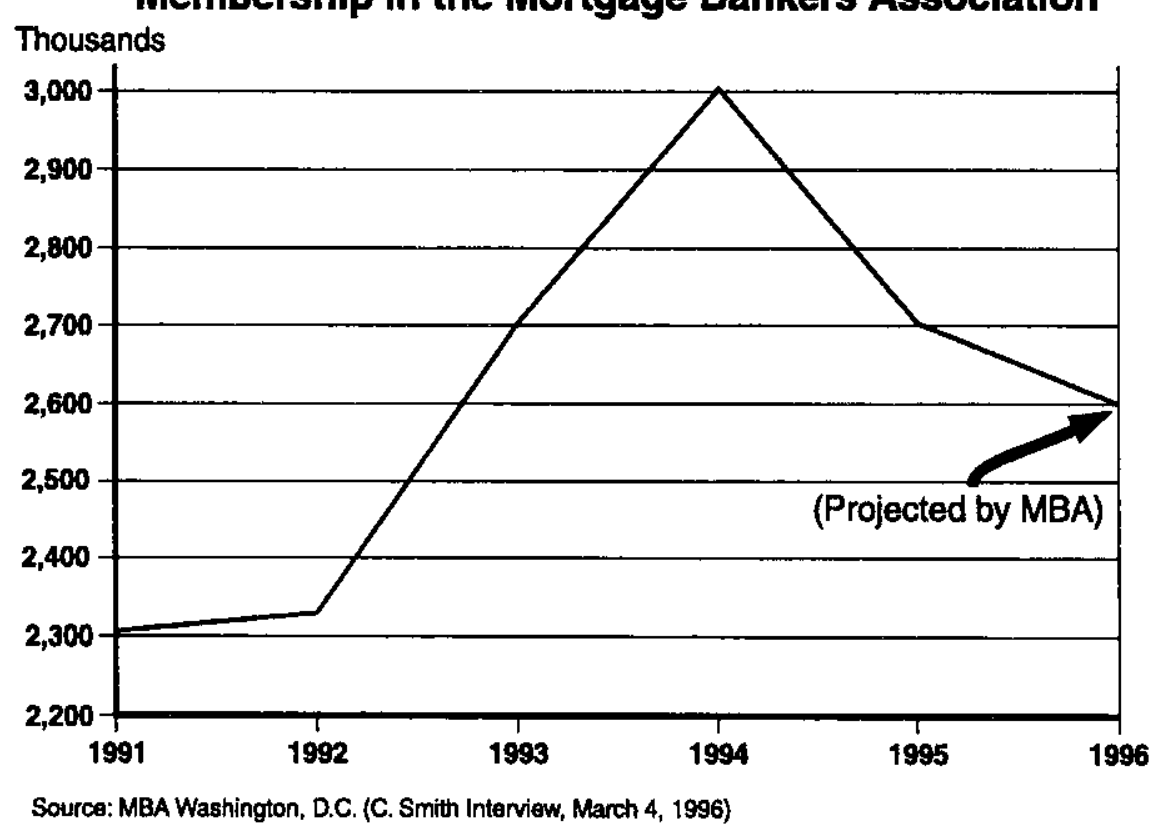

shown in Table 1. While some sites are home pages of individual properties for sale, others offer more than 500,000 listings across the country. Only partial marketing and purchasing information is on the majority of the web sites, but comprehensive real estate services loom on the horizon of this frontier.

This report includes seven sections. Section 2 investigates technology's effects on the real

estate brokerage market, both present and future. Section 3 shows how technological advances will continue to influence the appraisal process. Section 4 examines the effects of technology on the primary mortgage market and Section 5 considers the secondary mortgage market. Section 6 explores the role of technology on the title insurance industry. Section 7 is the conclusion.

Figure 4. Legal Services Employees: SIC 81

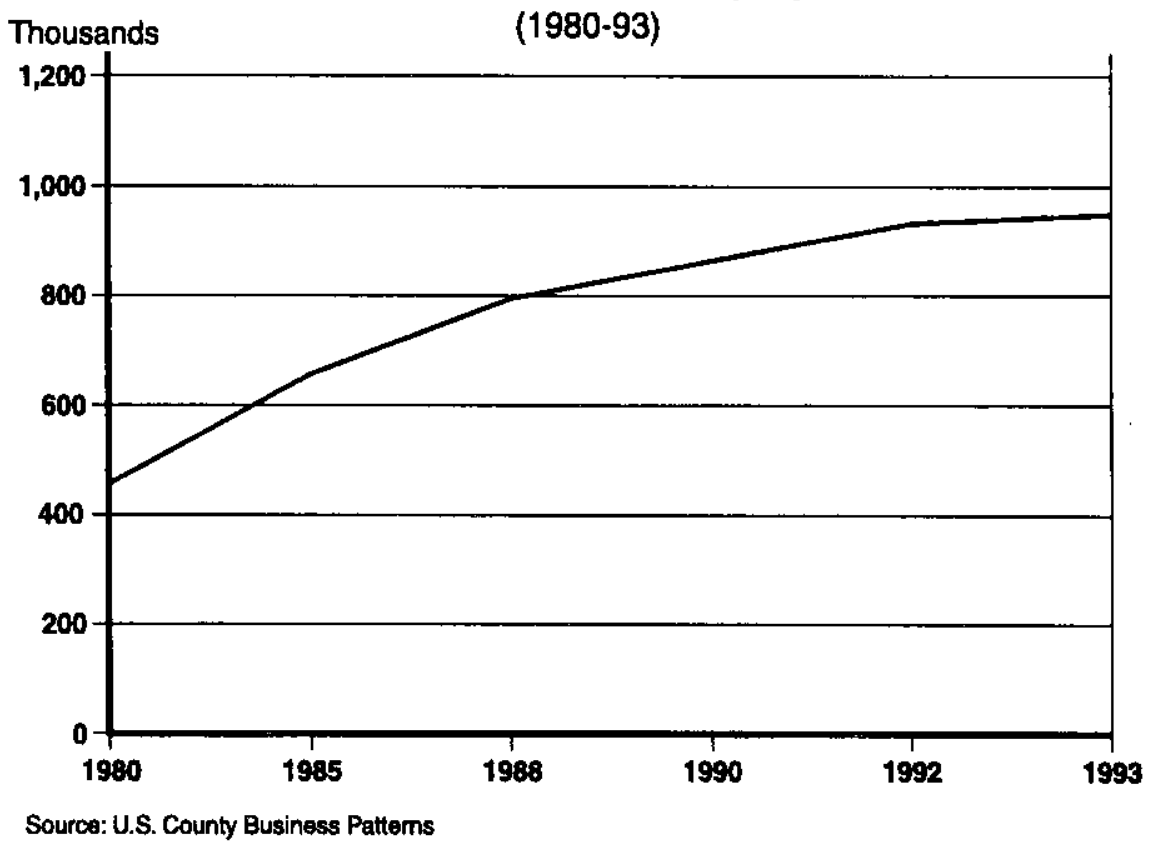


Figure 5. Subdividers and Developers

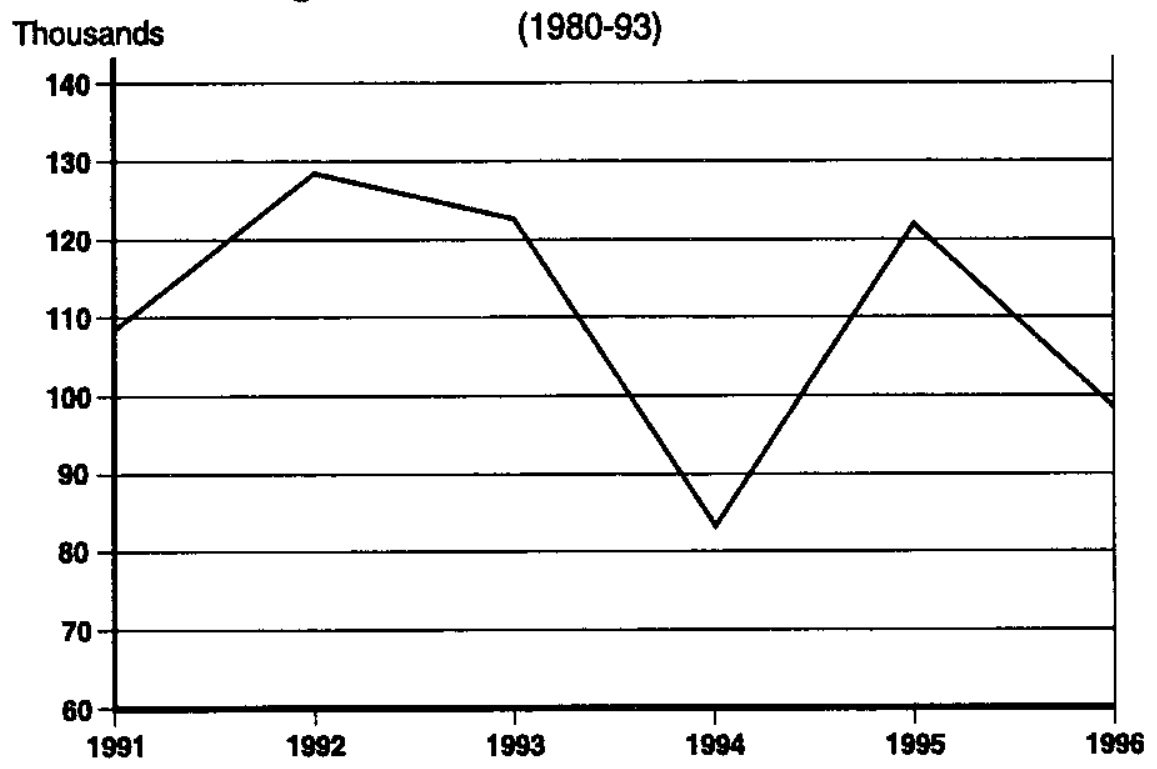

Source: U.S. County Business Patterns

\section{Real Estate Brokerage}

\section{Technology Implications}

Real estate agents in the United States provide valuable services to homebuyers and sellers. While professionalism, technical information, ethics, financing information and third-party negotiations have long been the hallmark and justification for relatively high real estate fees of 6 to 7 percent in the United States, commission rates average only 3 to 4 percent in South Africa and New Zealand and 3 percent in the United Kingdom. No measurable difference, however, has been demonstrated in the quality of services rendered outside the United States.

Information inefficiencies in the residential real estate market are being capitalized into real estate agents' marketing fees. In any local real estate market, information is power. This power has been controlled directly by real estate agents via the National Association of Realtors (NAR) and its affiliated local chapters, and indirectly through the Multiple Listing Services' (MLS) barriers to entry for non-NAR members (Braswell and Poe, 1992).

Benjamin and Chinloy (1995) acknowledge high transaction costs of real estate brokerage. They offer a methodology of valuing the technological innovation of electronic lockbox systems that provide keyless entry, enhanced security and reduced communication time; they conclude that sellers adopting the technology will achieve higher sale prices in shorter marketing periods. Their conclusion that technology will increase sale prices is questionable if innovations are adopted throughout the market place. It implies that transaction costs (i.e., commissions) are fixed and that any efficiencies and reduction in selling time will be captured only by sellers. Three parties, however, are affected by technological innovations and increased market efficiency: buyers, sellers and real estate service providers. Improved technology and efficiency are expanding consumer understanding of traditional marketing approaches that are being seriously challenged. Two markets operate independently: technology will divide the real estate market (buyers and sellers) and the real estate marketing market (licensed agents and associated service providers). Until now, they have been one in the public's mind.

Power struggles and litigation over authorized access to Realtor housing market information are being challenged seriously by the drive for increased efficiency through technology and the rapid emergence of "free" information on the Internet. The real estate "open market" marketing revolution will further test and question who owns market information on particular homes or sales. The free information 
market explosion leads to the following viewpoints about future ownership of real estate market information:

Realtors generally harbor the traditional view that data about property and sales are proprietary information, belonging only to authorized members of NAR and local boards.

Buyers and sellers increasingly hold the viewpoint that they create the information and, therefore, own it. They believe that they reserve the right not to disclose asking and sales prices to the marketplace.

Tax assessor/collectors are under increasing pressure to disclose and publish market information about specific and generalized sales data. The information highway bolsters the theory that specific comparable sales information used to calculate taxable values and federally insured loans belongs in the public domain. Many ad valorem tax office property sales databases are accessible on disks, magnetic tapes and public on-line services. Information generally sells for 2 cents per comparable.

Appraisers who collect and maintain comparable sales data believe they own the information collected and maintained in their databases.

If information is power, and more information about real estate markets becomes available to the general public through technology, a transfer of this power to consumers will devalue information and services previously available only through Realtors and other real estate licensees. Their industry may be close to imploding, as they cannot agree on the vehicle to disseminate real estate information. Rosen (1996) finds, "Underlying the squabbling (among agents) is the very real specter that the information-laden Internet and World Wide Web could replace much of the public's need for agents' traditional house-hunting services. The fear mongers' theory is simple: If buyers and sellers can sit at their PCs and Macs and gather enough information about each other's offerings-and even make offers--why should they pay agents?"

NAR has named its listing access vehicle Realtor Information Network (RIN); it is designed to retain agents' control of the information and keep consumers out of the loop by charging $\$ 180$ / per year per broker/ agent, an $\$ 8$-per-hour access fee and $\$ 1$ per listing posted, according to Rosen (1996).
Local boards are creating their own Internet systems open to the public and also are charging their agents local access fees and listing fees; Microsoft's network system, Real Direct, posts any listing for only 15 cents. Technology is transforming and transferring valuable information previously monopolized by the real estate profession into a free service.

\section{Current Technological Innovations} and Resources

- Internet real estate listings are located at more than 8,000 web sites, with daily improvements in the information offered about specific properties, photos, usable neighborhood information and so forth.

- The MLS data are available in several cities on CD-ROM and updated weekly. Each disk contains 12 months of market data and offers valuable search options (Digital Data Systems, Inc., Irving, Texas).

- Electronic and fax transfers of listing contracts and offers to purchase have become acceptable business practice, thereby reducing transaction costs, services required and time.

- Satellite auctions and property marketing channels are available.

- Licensed telemarketing agents are interviewing homeowners for listings.

- E-mail, voice mail, cellular phones and pagers have increased individual agents' efficiency and productivity.

- Long distance learning, seminars and franchise meetings are presented via satellite and video-phone conferencing technology.

- CD-ROM contract forms have added efficiency, standardization and professionalism to the preparation of contracts, leases and other documents used by the industry.

- Electronic cameras are replacing traditional ones. Photographs are transmitted electronically and can be downloaded into a computer's hard drive. Cameras that can store up to 300 photographs will extend on-line home viewing beyond the traditional exterior view to show even landscaping, the home's interior and neighborhood scenes. This will likely reduce the number of homes physically inspected by the average buyer. 
- Electronic transfers of home photographs and information are being transferred to videotapes and shipped overnight to prospecive buyers around the globe.

- Traditional real estate classified ads and photographs are being offered on the Internet at no charge. Reduced classified advertising budgets may reduce transaction costs for agents, sellers or both. (See, for example, the Dallas Morning News' Internet real estate listings at http:/ / cityview.com/dallas.)

\section{Anticipated Changes in Real Estate Marketing}

- Availability of complete property-specific and market information to all market participants, not just to members of NAR through its MLS monopoly, will become a reality shortly.

- The increased availability of and demand for merged databases about macro- and micromarket information beyond property prices and trends will include, but not be limited to, statistics on crime, the environment, local school performance on national exams, ad valorem tax rates and historic appreciation rates.

- Increased productivity on sales per fulltime agent in major markets will result in a gradual decline in the total number of active real estate agents.

- Overall service and face-to-face customer contact time required by agents to complete real estate transactions will be reducec greatly.

- A general decline in real estate commissions over time, with fixed marketing fees per transaction, will become the norm.

- The trend is toward agents offering support services that traditionally have been provided by others, such as collateral assessments (i.e., valuation) for loan processes, loan originations, property inspections, coordination of required repairs, coordination of property closings between buyers/sellers and electronic transfers of closing papers to mortgage lenders.

- Large franchise brokers will grow, providing links in services and products currently associated with property ownership. Specifically, these brokers will provide services such as: (1) free hotel rooms for homebuyers through ownership of hotels by major real estate franchises (Millman, 1995) ; (2) home renovations and repair; (3) lawn care and maintenance; (4) home moving, storage and transfer businesses; (5) home warranty plans and insurance; and (6) onestop shopping for homeowners, health, life and auto insurance. ${ }^{2}$

- Prospecting for listings will be the job of professional, licensed real estate agents who will telemarket sellers and search Internet home pages, thereby accelerating competitive pricing for real estate services.

\section{Real Estate Appraisal Services}

\section{Technology Implications}

Technology and the growing availability of real estate databases have reduced regulatory requirements for appraisals by banks on houses valued at less than $\$ 250,000$. Appraisal requirements by mortgage investors in the secondary mortgage market have been relaxed also. The generally less volatile housing market in the United States today, compared to the 1980s, generates less demand for traditional appraisals and, therefore, appraisers' services in the short term.

LaDuca (1996) offers a justification for appraisers within the traditional real estate marketplace: "Appraisers have defended their existence by statements about the uniqueness of property, the importance of personal inspections and the complexity of an appraisal problem." He reports, however, that for a banking official who uses an appraisal, "... within five years, 70 percent of appraisals will be in a simple, (fully) automated format, and the other 30 percent will require more traditional appraisal formats." He concludes that with the growth of structured databases, more appraisals will be automated, resulting in fewer appraisers who will be paid less money to complete more appraisals in less time.

The media are now covering the implications of technology on the appraisal industry. For example, one of the premier appraisal magazines ran a lead cover story by Branner (1995) entitled, "Artificial Intelligence: Is It Taking Your Job?" The author finds that both 
banks and the secondary mortgage market have "... made a decision to allow the use of nonlicensed appraisers for some collateral assessments." O'Donnell (1995) writes in Real Estate Valuation Magazine, "Whereas at one time, appraisers were relied upon for their independent knowledge and judgment, they are now being forced to conform their opinions to computer-generated adjustment grids, regression analysis and statistical norms. In fact, many of the larger lending institutions have moved to "intelligent" (i.e., artificial intelligence program-generated) appraisals where the computer decides which comps are appropriate."

Regan (1996) reports that Freddie Mac has adopted and implemented an automated "collateral assessment" feature as part of their new Loan Prospector Program ${ }^{\mathrm{TM}}$ using a nation-wide network of real estate agents and brokers who merely drive by subject properties to make exterior inspections and "fraud checks." The current automated appraisals are available for 100 counties across the United States with projections to include 350 counties by year-end 1996

These and other innovations and initiatives by a secondary mortgage market participant are extremely significant from the standpoint of traditional professional banking and appraisal practices:

- Independent certified appraisers are not used.

- In-house, primary lender, "on staff" appraisers are not used.

- Interior inspections are seldom required.

- The request for valuation is ordered independently by secondary mortgage investors, not by the home purchaser or primary lender.

- Mass appraisal firms ". . typically (will) receive a little more than half the fee they generally receive (currently)." ${ }^{3}$

- The transaction and evaluation time required is reduced from weeks to days or even hours.

This, of course, raises the question of who is at risk or responsible for "overvaluation" of houses and lending risk and/or loan losses; supposedly this transfers all valuation risk or negative loan values/losses to the secondary mortgage market. Freddie Mac's Vice President of Automatic Underwriting, Peter Masalli, has stated, "We offer a collateral assessment solution for all risk profiles, relieving lenders of this responsibility, as well as the need to represent and warrant appraisals" (Regan, 1996). The implication of this statement, if adopted by the entire secondary mortgage market, would set the scene for a partial bypass or complete elimination of both appraisers and primary lenders in the marketplace, allowing homebuyers to proceed directly to the secondary mortgage market for loan application, underwriting, approval and funding.

In the new technological marketplace, many inefficient real estate services are likely to be eliminated altogether. Warren (1996) notes, "Appraisers also are watching with anxiety the development of computerized appraising. Some note that lenders are experimenting with computer programs that could render the profession obsolete." The secondary mortgage market may become the primary and only mortgage market.

Some appraisers, however, have embraced the concepts of artificial intelligence appraising (Raburn and Tosh, 1995), computer assisted appraisals (Detweiler and Radigan, 1996) and cyberspace appraisals (Gilon and Cardenas, 1995). This likely will accelerate the trend toward less human involvement, fewer appraisers and lower fees. Some solace for appraisers is offered by Worsala, Lenk and Silva (1995) who caution both appraisers and the banking industry. They find the use of neural network appraising presents serious questions about the reliability of computergenerated valuation conclusions compared to traditional approaches.

\section{Current Technological Innovations, Trends and Resources}

- Electronic Data Interchange or EDI (paperless appraisals via modem or satellite)

- Electronic cameras and digital imaging that interface with PCs and appraisal reports

- Floor plan sketching and area calculation using CADD programs

- Site Plan (lot plat and structure platting)

- Electronic transmission of appraisals (O'Rourke, 1995)

- Access to county courthouse records online (Schwartz, 1995) 
- Artificial intelligence computergenerated appraisal (O'Donnel, 1995)

- Integrated computer software that merges report forms, sketches, maps, photos and demographic information (Residential Appraiser software, 1996)

- Consolidated home appraisal regulations and updates (AllRegs, 1996)

- On-line environmental reports (Marshall and Sw:ft, 1996)

- Replacement cost estimator (Marshall and Swift, available for several years)

- Portable, hand-held Newton ${ }^{\circledR}$ Message $\mathrm{Pad} B$ and printing of property inspection reports (Manning/RAL Information Services, 1996)

- Freddie Mac's statistically-based models for assessing collateral nationwide (1996)

- Freddic Mac's agreement with real estate agency affiliates of the Mortgage Guaranty Insurance Corporation (MGIC) to offer aciditional collateral assessment alternatives

- Fannie Mae's Mini-URAR Form 1095 and Form 2055 for "drive-by" appraisals (October 1995)

- FNMA's 1996 adoption of TRW Credit Reporting Services' REDI National Property Information databases

- Availability of digitized, on-line flood certification services

- Geographic Information Services (GIS) desktop mapping, demographics and neighborhood identification programs (e.g., Map Info, Arc Info, TIGR)

- Reduced commercial appraisal fees, such as the fee for a 200-unit apartment complex decreasing from an average of $\$ 4,000$ in 1993 to $\$ 2,500$ in 1996 (Warren, $1996)^{4}$

\section{Non-Core Business Innovations}

A seriously reduced demand for residential real estate appraisals and, therefore, appraisers, is anticipated. New, non-core business appraisal activities should include:

- Home :nspection services

- Business valuation services

- Environmental assessment services

- Investment and disposition consulting
- Lead-based paint assessment, inspection, abatement and other related activities (Branner, 1995)

- Ad valorem tax consulting and property owner representation (although technology may eliminate this business in a few years)

- Future refinements and use of computergenerated appraisals

- Creation of "spot check" audits, whereby FNMA, mortgage originators or both perform traditional appraisals to measure the accuracy of artificial intelligence

\section{Primary Mortgage Market}

\section{Technology Implications}

Technology has played a major role in the emerging "new bank" and in commercial bank downsizing. The number of bookkeepers, receptionists and secretaries has declined significantly, the result, in part, of banking executives preforming many secretarial support tasks (e.g., word processing and spreadsheets) and similar duties and using email, voice mail and faxes by modem. ATMs have replaced many tellers, while advances such as electronic deposit and withdrawal capabilities have transformed the relationship between banks and their customers so that they seldom, if ever, come into face-to-face contact.

Fax/modem consumer loan applications provide 24-hour service and funding guarantees. The need for faithful and friendly customer service at the teller's window has been minimized to the point that many banks are charging "personal teller window service" fees for each transaction. Customer loyalty also has begun to evaporate; it is difficult to form relationships with ATM machines and automated telephone voice-mail account executives. These new banking environment features are on the cutting edge--where many real estate services are likely to be in the near future.

Banks, thrifts and mortgage companies downsized in several regions of the country in the late 1980s, the result of bankruptcies and forced government closures. Many closures were related to bad real estate loans (Ghosh, Guttery and Sirmans, 1996). Subsequently, many regional "superbank" mergers and expansions (e.g., NationsBank, Midatlantic 
Bank, Meridian Bank, Chemical Bank) have closed many previously competing branches, further reducing banking employment.

Even downsized, more efficient and technologically improved banks that may be enjoying prosperity are now being challenged severely by new, nonregulated "nonlocation nonbanks" using only mail and telephone line transactions. These nonbank "branches" are located in every home with a telephone, or mailbox or both. An article by Cocheo (1996) in the ABA Banking Journal, entitled "USSA: Stealth Bank or 'Bank' of the Future," suggests both traditional and nonbanks will be faced with even more competition from Internet banking. Lunt (1996) reports Security First Network Bank (Internet http://www.sfnb.com), for example, is open 24 hours per day, 365 days per year. During its first two weeks of internet operation, 750 new depositors from 32 states opened accounts.

Since 1990, many depositors and real estate borrowers have used both automated direct deposits and mortgage payment debits. Rules are in place to protect a customer's funds in case of electronic errors under the 1995 Federal Reserve Electronic Funds Transfer Act and the National Automated House Association Guidelines (Dunsmore, 1996). The concept of the fully automated bank is a reality in terms of deposits, withdrawals, savings and checking accounts, consumer loans and credit cards. The challenge will be to determine how real estate loans will be originated, underwritten and serviced, as well as by whom. As the new technological era (i.e., the Internet) moves relentlessly toward increased efficiency, speed and reduction of many real estate service providers, the secondary mortgage market and consumers may by-pass primary leaders altogether.

\section{Technology Innovations}

- Electronic deposits and withdrawals have created instantaneous, on-time mortgage payments. Insufficient funds in the mortgagor's account creates immediate mortgage default.

- Mortgage interest rate bulletin boards and "electronic listing services" will provide increased competition in mortgage lending rates, thereby driving rates down, ceteris paribus.
- Faxed mortgage applications and other real estate documents are common.

- Internet loan applications will be posted by potential borrowers who will then receive "bids" or offers on loans from lenders. This role reversal will result in lenders seeking borrowers, not vice versa.

- Growth of Internet banks with distant or nonpublic facilities will increase competition with traditional banks, reduce overhead and make interest rates more competitive.

- Growth of nonbanks (e.g., G.E. Capital, USAA) will increase competition, the result, in part, of reduced regulation.

- Reduced mortgage loan application time is a result of electronic verifications and credit checks as well as relaxed appraisal requirements for loans less than $\$ 250,000$.

- Electronic secondary loan sales, approvals, commitments, purchases and transfers are becoming commonplace.

- Computer-generated loan application programs with built-in, automatic audit and verification features are being developed by larger lenders.

- Computer-generated mortgage documents for each loan type are being produced and provided to borrowers at the time of loan approval.

- Remote telemarketing of mortgage lending, refinancing equity loans and home improvement loans is a growing trend.

- Computerized loan origination networks offer point-of-sale loan origination within real estate brokerage offices.

\section{Secondary Mortgage Market}

\section{Technology Implications}

The Federal National Mortgage Association (FNMA or Fannie Mae) and the Federal Home Loan Mortgage Corporation (FHLMC or Freddie Mac) have taken the lead in implementating applied business computing and technology. These mortgage investors anticipate other real estate industry participants will follow suit. FNMA and Freddie Mac know they control the residential mortgage market; therefore, they can require others to follow their rules and standards and to use 
their computer programs and technological innovations.

This new methodology affects primary lenders, appraisers, mortgage servicing firms and, ultimately, homebuyers. This shift in power comes: in part, from the secondary mortgage market participating in virtually all loan types, including fixed-rate mortgages, adjustable-rate mortgages, graduated-payment mortgages, growing-equity mortgages, manufactured housing loans, construction loans, second mortgages, federally funded public housing loans and jumbo loans for both singlefamily and multifamily dwellings.

Lenders' initiatives and technological innovations have poised them to conduct mortgage operations at every level. These include, but are not limited to: (1) customer-buyer education about residential and investment properties, (2) direct lending activities, (3) traditional and new loar products for primary lenders and (4) development of new markets and operating systems services through computer software and technologies that are copyrighted and retain their trademarks. The many innovations initiated by Freddie Mac (e.g., the automated Loan Prospector) and Fannie Mae (e.g., Desktop Originater $\mathrm{r}^{\mathrm{TM}}$ and Desktop Underwriter $\mathrm{r}^{\mathrm{TM}}$ ) are fully autcmated, desktop personal computer programs that organize borrower information, qualify borrowers for the appropriate loan, perform underwriting tasks and prepare associated documents in a standardized format and quality. While primary lenders generally collect borrower information, originate mortgage loans and eventually sell the loans in the secondary mortgage market, some streamlining and efficiency could allow FNMA, GNMA and FHLMC to loan directly to borrowers. Innovations, initiatives and policies in the secondary market will facilitate significant changes in the entire housing market in the near future.

\section{Technology Innovations}

- Fully automated and electronic information systems that include such programs as Desktop Trader ${ }^{\mathrm{TM}}$, Rate Sheet Express ${ }^{\mathrm{TM}}$, Market Express ${ }^{\mathrm{TM}}$ and

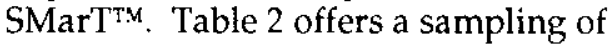
publications and technology innovations in this area.

- Acceptance of EDI transfers of appraisals

- Creation of Form 2055 that permits driveby appraisals
- Desktop Underwriter' ${ }^{\mathrm{TM}}$ risk assessment of loans

- Creation of borrower credit scoring, which consolidates electronically and simplifies the credit report status to a single number

- Freddie Mac's statistically-based models for assessing collateral nationwide

- Electronically automated, on-line flood certification services

- MGIC's network of real estate agents used to perform collateral assessments.

\section{Title Insurance Industry}

\section{Technology Implications}

Title companies provide important title information and guarantees for buyers and lenders; technology is influencing them as well as courthouses and ad valorem tax offices. Many courthouses and tax offices are merging information by assigning shared property or parcel identification numbers. Public records are being transferred to electronic data files that can generate a complete historic "chain of title" that is updated daily as new documents are filed on individual properties.

Rampy (1995) reports that one firm reduced 30 file cabinets of documents to $18 \mathrm{CD}-\mathrm{ROM}$ discs at a cost of 8 cents per page. Title company microfilming is being replaced rapidly by computer output to laser disc (COLD), compact discs or optical discs that allow computer-generated reports on mainframes to be transferred on-line. Conceivably, the public sector could provide title and tax reports in a usable form on demand directly to anyone desiring title and tax information. While interpretation and assurance of marketable title require professional opinions, organized, precise title and tax information is quickly replacing out-moded title searches through historic documents.

Title companies' on-staff attorneys traditionally have provided important closing or escrow services that extend beyond insuring the title of a particular property, including the preparation of deeds and mortgages. Technology is challenging who may provide these services, however. Virtual Lawyers ${ }^{\mathrm{TM}}$ and Real Estate Lawyer ${ }^{\mathrm{TM}}$ (Outlook Software Corp., Dallas, Texas) are software programs that create customized, legally-binding real estate documents, including sales agreements, 
residential and commercial leases, mortgages and deeds. It remains to be seen whether or not the legal profession and title companies will transfer their services to lenders, the secondary mortgage market or others. Increased competition and efficiency resulting from technology will have major implications for them as well.

\section{Technology Innovations}

- Courthouses are replacing microfilm with COLD, CD-ROM and optical discs that provide computer-generated reports on individual properties.

- Instant tax certificates and summary "chain of title" reports on individual properties will be available to the general public.

- Electronic transfers and filing of papers will become a reality after notary and verification of signature technologies are developed.

- Primary and secondary mortgage market participants will request title reports and insurance from regional wholesale title insurance companies.

- Increased accessibility and retrieveability of title and tax information from courthouses (Adams, 1996), the result of improved technology, will challenge state-imposed title insurance premium rates (as in Texas) and the proposed required use of lawyers for title opinions (as in Virginia).

- The cost and charges for document preparation associated with property transactions will decrease, the result of both widespread availability of Real Estate Lawyer and similar software and of the consolidated services of primary and secondary mortgage service providers.

- Proposals are for all county title records to be on-line and available to the public (Schwartz and Yates, 1995).

- Increased competition and technological innovations will lead to national competitive pricing of title insurance policies, thereby eliminating state-imposed laws and other restrictive barriers (Adams, 1996).

\section{Conclusion}

The implications of technology for the real estate profession, industry and market are profound and will have a serious impact on virtually all aspects of and participants in this relatively inefficient, high-transaction-cost business. The traditional real estate transaction of the twentieth century (see Figure 6), when contrasted with the real prospect of the twenty-first century cyber-technology-driven market of the near future, has startling

Figure 6

\section{0th Century Traditional Real Estate Transactions}

Participants and service provlders $=16+$ Participants

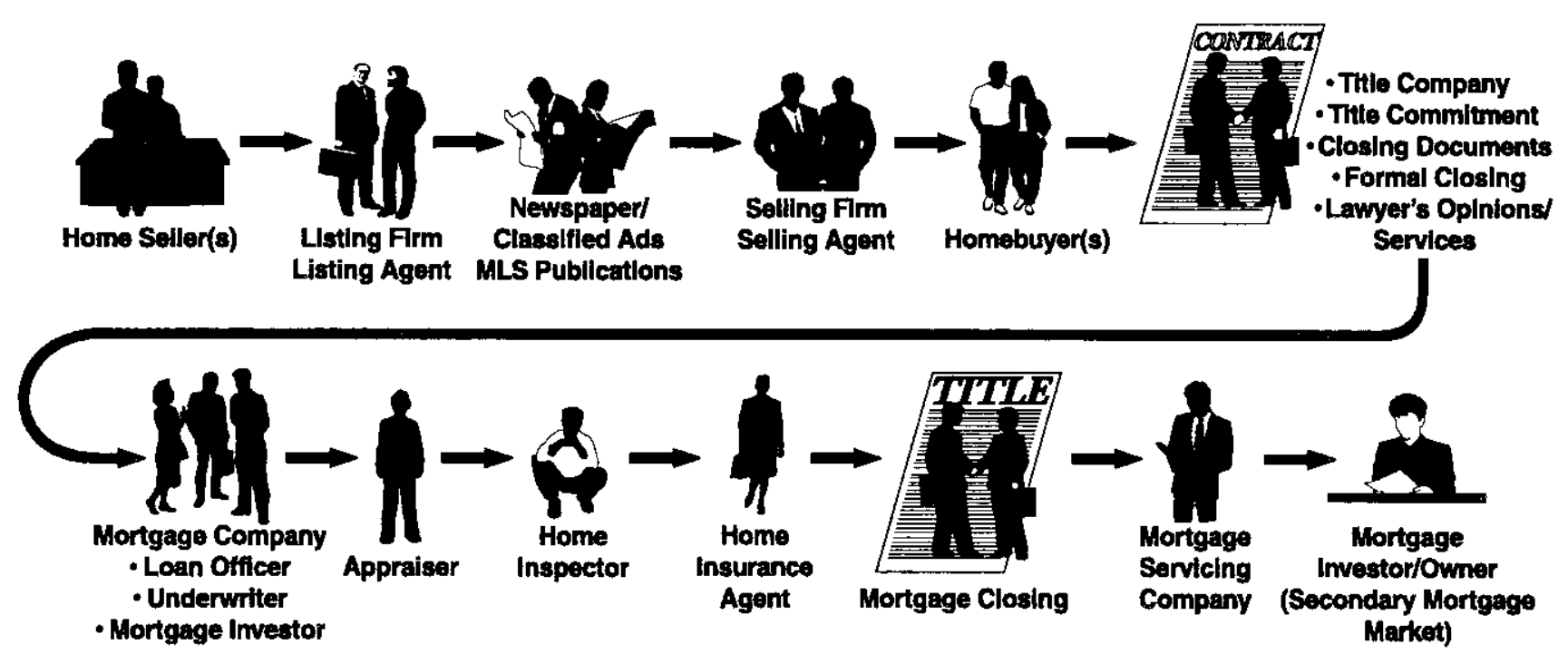




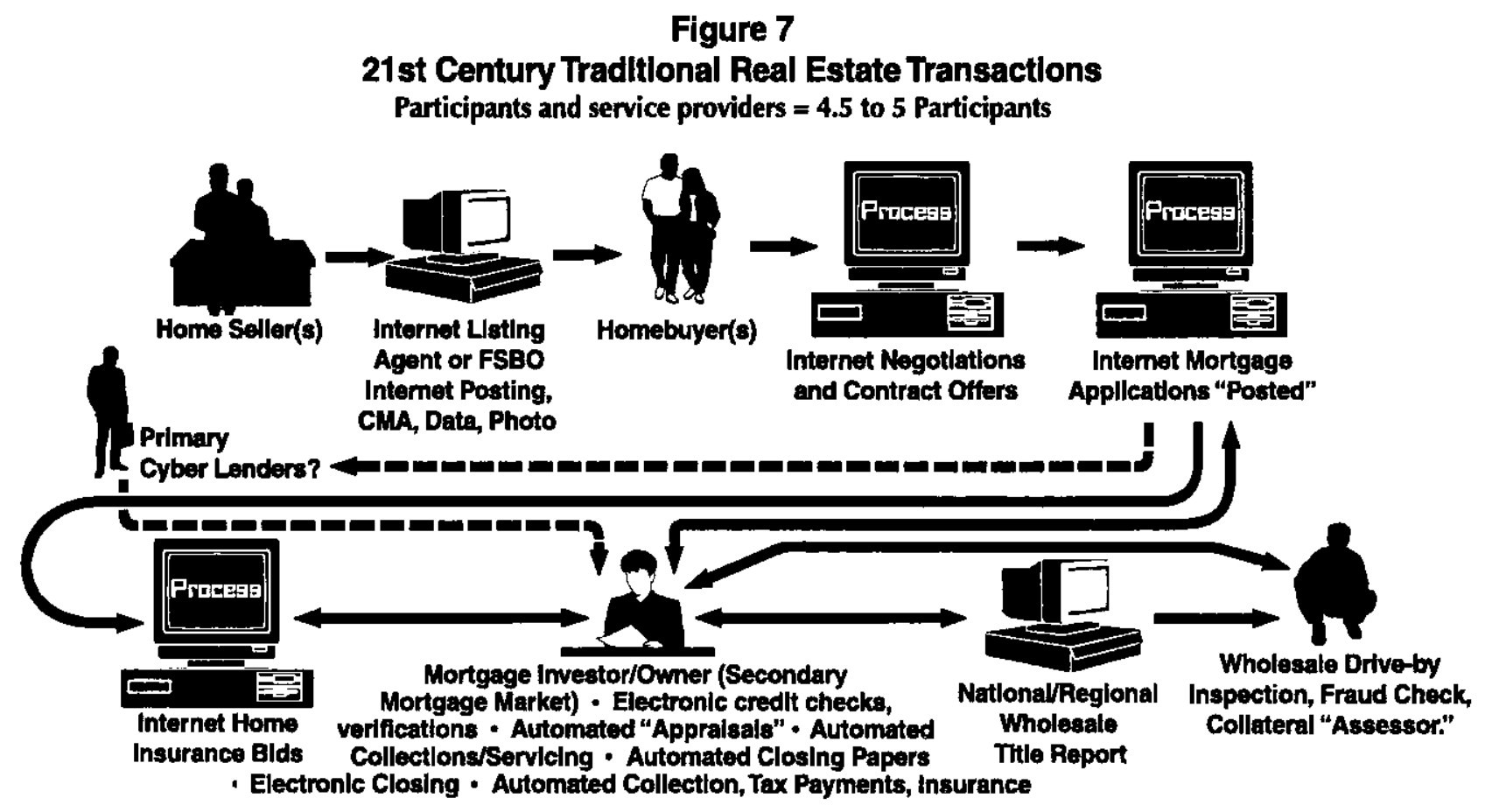

implications for the real estate profession. Serious downsizing in the number of required service providers is likely, as well as a reduced total cost per transaction (see Figure 7).

Reduced transaction costs (see Table 3 ) and requisite increased efficiencies in the marketing process will amount to a wealth transfer from licensed agents, lenders, appraisers, attorneys and loan servicers to buyers and sellers. The real estate profession will pay a tremendous cost in terms of employment and income.

Gilon and Cardenas (1995) offer the following signpost to the future: "Bill Gates, chairman and founder of Microsoft Corporation,

the world's largest computer software company, recently identified real estate as one of the industries that will be revolutionized by technological change. The change has already started and is moving at a fast pace; those who realize this and welcome it will ensure their survival in the profession." Only time will tell if technology and the real estate profession are compatible. Is real estate an art or a science? Is real estate a unique asset or just another commodity to be purchased and sold? More research is needed immediately to study the logic and direction of technology and its ramifications for consumers, financial institutions and real estate participants. 
Table 1. Real Estate Web Sites Overview

(Selection from more than 4,000 created since January 1995)

\begin{tabular}{|c|c|c|}
\hline Site & Real Estate Network & Location \\
\hline 1 & $\begin{array}{l}\text { IRED_International Real Estate } \\
\text { Directory } \\
\text { Global directory of real estate World } \\
\text { Wide Web sites }\end{array}$ & http: $/ /$ www.ired.com \\
\hline 2 & $\begin{array}{l}\text { NAR-HomeSelect } \\
441,000 \text { homes in } 37 \text { st ates and } 94 \text { cities, } \\
\text { photos, no addresses, amenity and price } \\
\text { search. }\end{array}$ & $\begin{array}{l}\text { http://www.realtor.com (NAR) } \\
\text { or } \\
\text { www.realtorads.com (HomeSelect) }\end{array}$ \\
\hline 3 & $\begin{array}{l}\text { Real Estate Center at Texas A\&M } \\
\text { University } \\
\text { Some } 8,000 \text { pages of data, news and } \\
\text { information on Texas and U.S. markets. }\end{array}$ & http://recenter.tamu.edu \\
\hline 4 & $\begin{array}{l}\text { Real Direct } \\
\text { Only three states, photos, complete } \\
\text { information and addresses, price search. }\end{array}$ & http $/ /$ www.realdirect.com \\
\hline 5 & $\begin{array}{l}\text { Home Web } \\
\text { Home search via zip code, photos, } \\
\text { commercial homes, land, good } \\
\text { information, few listings, price search. }\end{array}$ & http://www.us_digital.com/homeweb \\
\hline 6 & $\begin{array}{l}\text { Home and Land Magazine } \\
200,000 \text { homes, ads from } 43 \text { states, price } \\
\text { and rental search. }\end{array}$ & http://www.homes.com/ \\
\hline 7 & $\begin{array}{l}\text { Coldwell Banker } \\
25,000 \text { homes in } 36 \text { states and Canada. }\end{array}$ & http://www.coldwellbanker.com \\
\hline 8 & $\begin{array}{l}\text { Fractalnet Real Estate } \\
\text { List of real estate firms by state and local } \\
\text { area. }\end{array}$ & http://www.fractals.com/realestate.html \\
\hline 9 & $\begin{array}{l}\text { Go Global } \\
\text { Only a few listings in four states. }\end{array}$ & http://www.goglobal.com \\
\hline 10 & $\begin{array}{l}\text { The Guide to Real Estate } \\
\text { Links } 209 \text { web sites in all } 50 \text { states and } 33 \\
\text { countries; also two for-sale-by-owner web } \\
\text { sites. }\end{array}$ & http://www.travelersonline.com/guide \\
\hline 11 & $\begin{array}{l}\text { HomeNet } \\
5,000 \text { properties in seven states, } \\
\text { investment properties for sale, good } \\
\text { information and area trends. }\end{array}$ & http://www.homenet.com/homenet.htm \\
\hline
\end{tabular}




\begin{tabular}{|c|c|c|}
\hline Site & Real Estate Network & Location \\
\hline 12 & $\begin{array}{l}\text { The Home Front } \\
\text { Central New Jersey homes. }\end{array}$ & http://www.homefrontbbs.com \\
\hline 13 & $\begin{array}{l}\text { Homes Internet Magazine } \\
\text { Custom search responds to users' } \\
\text { e-mail addresses. }\end{array}$ & http://www.homesmag.odc.com/ \\
\hline 14 & $\begin{array}{l}\text { Listinglink } \\
\text { Across the nation, photo of homes, } \\
\text { advertising type information. }\end{array}$ & http://www.listinglink.com \\
\hline 15 & $\begin{array}{l}\text { Matchpoint } \\
\text { Scattered states, will search and respond } \\
\text { to e-mail address, anonymous I.D. option } \\
\text { and price change notifications. }\end{array}$ & http://www.nji.com/mp \\
\hline 16 & $\begin{array}{l}\text { New York Real Estate Guide } \\
\text { Apartment sales and rentals in New } \\
\text { York, cross links to tirms' web sites. }\end{array}$ & http://www.nyrealty.com/ \\
\hline 17 & $\begin{array}{l}\text { The Property Network } \\
\text { 7,000 Dallas/Fort Worth MLS homes, } \\
\text { good intormation and addresses, I.D. } \\
\text { zequired. }\end{array}$ & http://www.texnet.com \\
\hline 18 & $\begin{array}{l}\text { RE/MAX International } \\
50 \text { states, three countries, few listings, } \\
\text { good information. Properties are listed on } \\
\text { Home Web. }\end{array}$ & http://www.remax.com \\
\hline 19 & $\begin{array}{l}\text { MN-Realty Web } \\
\text { Minneapolis-St. Paul area homes. }\end{array}$ & http://www.mnrealty.com \\
\hline 20 & $\begin{array}{l}\text { Welburne \& Purdy } \\
\text { Upstate New York homes, color photos, } \\
\text { operated by above firm. }\end{array}$ & http://www.global2000.net/w\%26P/ \\
\hline 21 & $\begin{array}{l}\text { Windermere Real Estate } \\
\text { Northwestern United States, good } \\
\text { information, color photos. }\end{array}$ & http://windermere.com \\
\hline 22 & $\begin{array}{l}\text { National Real Estate Exchange Network } \\
\text { Maui, Hawaii properties for IRC Sec. } \\
1031 \text { tax-deferred exchanges. }\end{array}$ & http://maui.net/ qmartyn/exchange.html \\
\hline 23 & $\begin{array}{l}\text { UnReal Estate Cartoons } \\
\text { Real estate humor. No information. }\end{array}$ & http://mindlink.net/rick_carlsen/ \\
\hline 24 & $\begin{array}{l}\text { Real Estate } 101 \\
\text { Color ado home regulations for buying or } \\
\text { selling in Colorado. }\end{array}$ & $\begin{array}{l}\text { http: } / / \text { www.databahn.net/trilakes/ } \\
\text { coloinfo.html }\end{array}$ \\
\hline
\end{tabular}




\begin{tabular}{|c|c|c|}
\hline Site & Real Estate Network & Location \\
\hline 25 & $\begin{array}{l}\text { Sand Dollar Realty } \\
\text { South Padre Island, Texas, resort area } \\
\text { listings. }\end{array}$ & http://rampages.onramp.net/-sandolar \\
\hline 26 & $\begin{array}{l}\text { Barbara Sue Seal Properties, Inc. } \\
\text { Portland, Oregon listings. }\end{array}$ & http://bsue.oneworldcom/ \\
\hline 27 & $\begin{array}{l}\text { Arnon Corp. of Ottawa } \\
\text { Commercial and apartment listings. }\end{array}$ & http://www.synapse.net/ arnon \\
\hline 28 & $\begin{array}{l}\text { California Association of Realtors } \\
\text { Los Angeles, California, regional } \\
\text { economic information and list of active } \\
\text { agents. }\end{array}$ & http://www.car.org \\
\hline 29 & $\begin{array}{l}\text { Hawaii Real Estate Network } \\
\text { Hawaii property listings. }\end{array}$ & http://www.hshawaii.com/hren \\
\hline 30 & $\begin{array}{l}\text { Worldwide Timeshare Mall } \\
\text { Timeshare listings, rentals and exchange } \\
\text { information. }\end{array}$ & http://timesharemall.com \\
\hline 31 & $\begin{array}{l}\text { Northern Virginia Association } \\
\text { of Realtors } \\
\text { Regional economics, articles and Virginia } \\
\text { Realtors information. }\end{array}$ & http://www.nvar.com \\
\hline 32 & $\begin{array}{l}\text { Maine Solar House } \\
\text { Solar home information. }\end{array}$ & http $/ /$ solstice.crest.org/renewables/wlord \\
\hline 33 & $\begin{array}{l}\text { NetEstate in London } \\
\text { London real estate information. }\end{array}$ & http://netestate.dsres.com \\
\hline 34 & $\begin{array}{l}\text { HomeScout } \\
\text { Real estate web site cross links. }\end{array}$ & http://homescout.com \\
\hline 35 & $\begin{array}{l}\text { Centex Homes } \\
\text { Home builder page, variety of } \\
\text { information. }\end{array}$ & http://www.cent ex-homes.com \\
\hline 36 & $\begin{array}{l}\text { Blackburn Real Estate } \\
\text { Mountain Home, Arkansas, real estate } \\
\text { consumer information. }\end{array}$ & $\begin{array}{l}\text { http://www.crl.com/-ozark/mtnhome/ } \\
\text { blackburn.html }\end{array}$ \\
\hline
\end{tabular}




\section{Table 2. Secondary Market Innovations, Publications and Computer Programs (Fannie Mae, 1995)}

\section{Technology Publications}

SmarT ${ }^{\mathrm{TM}}$ for MORTNETPlus

Secondary marketing strategy programs that minimize risk, maximize yield and link with Desktop Originator ${ }^{\circledR}$ and Desktop Underwriter ${ }^{\circledR}$.

Desktop Home Counselor ${ }^{\mathrm{TM}}$ Version 2.0: For Lenders Provides information on benefits, functional enhancements, affordability, analysis, credit report and reconciliation.

Desktop Trader ${ }^{\mathrm{TM}}$ Automated electronic FNMA cash prices, take-down cash commitments and contract numbe: allocations from any remote location via a personal computer.

Rate Sheet Express ${ }^{\mathrm{TM}}$ Automated broadcast fax services to multiple locations on current loan rates and so forth.

Market Express ${ }^{\mathrm{TM}}$

Detail mortgage finance information on all loan programs; updated daily.

Guide Express ${ }^{\mathrm{TM}}$ by ADFINET Administrative directives and automated library of secondary guidelines (e.g., FHA, VA, RESPA)

MORNETPlus: Equipment information

Funding Express ${ }^{\mathrm{TM}}$ Morne-Plus electronic submissions of loans, reports and detailed loan-level information.

\section{Multifamily Publications}

Financing Multifamily Targeted Affordable Housing Refinancing and direct loan initiatives for new construction or refurbishing low-income housing.

A DUS Primer

Multifamily financing information about FNMA's Delegated Underwriting and Servicing (DUS) lenders.

Multifamily DUS

Multifamily convertible ARMs

FannieMaps® version 1.2: Explore Untapped Markets Computerized mapping of mortgage market opportunities merged with census data, demographic information and neighborhood household information.

Guide to Homeownership (audio and Braille versions) 


\section{Customer Education Publications and Marketing Innovations for Lending}

Originating Residential Mortgages: Strategies for Increasing Mortgage Loan Production FNMA Mortgage marketing kits for marketing loan products to real estate agents, borrowers and for taking loan applications.

Becoming a Landlord: Rewards, Risks and Responsibilities for Owner-Occupants of Two-to-FourFamily Homes

Direct and lender marketing of loan products to prospective investors (buyers-borrowers) in two-to-four-family investment properties. Kits and workbooks for seminars and classroom use.

Foreclosure Prevention Workbook

Designed to help lenders and borrowers prevent foreclosure and to work out delinquencies.

\section{Affordable and Special-Needs Housing Publications for Lenders and Borrowers}

Opening Doors with Fannie Mae's Community Lending Products: brochure

Opening Doors with Fannie Mae's Community Lending Products: complete kit

Tools You Can Use to Open More Doors to Homeownership

Guaranteed Rural Housing \& Rural Direct Loan Leveraging Programs

Community Living ${ }^{\circledR}$ Information for Lenders

Community Living ${ }^{\circledR}$ Information for Borrowers

Community Banks: Doing Business with the Secondary Mortgage Market

Community Lending Quarterly

Fannie Mae's Community Homebuyer's Program consumer booklets. Available in English, Spanish and Chinese.

\section{Marketing Publications}

One-Month LIBOR-Indexed ARMs with Payment Caps

London InterBank Offered Rate 30-year loan/U.S. dollars with monthly interest adjustments and annual payment adjustments.

FHA/VA Adjustable-Rate Mortgage-Backed Securities (MBS)

Pooling of current production mortgages at lower FNMA pricing, pooling structure and funding options.

\section{ARM Flexß Plus}

Flexible servicing fee structure, at both individual loan level and pool level, by trading off excess servicing on fixed MBS margin pools. 


\section{Marketing Publications (continued)}

ARM Fanne Majors ${ }^{\circledR}$

Flexible pooling options for adjustable-rate mortgages.

Document Custody Services for MBS

Fannie Mae's Document Delivery Facility (DDF) accepts loan documents for MBS and allows retrieval of individual loan information.

Release of Loan Documents from DDF

Electronic requests of loan document (copies or originals) are processed within 48 hours.

As Soon As Pooled $\circledast$ Plus

Lenders can perform electronic transfers on individual loans within mortgage pools, allowing funding, pooling, repooling, clearance and document custody services within 24 hours of request by lender.

MBS Loan-Level Servicing Transfers

Electror.ic servicing transfers allows the purchase, transfer and/or retention of servicing on individual loans within FNMA pools.

MORNET Loan Stratification System (LSS®)

Electronic 1,100-character format stratifies, sorts, classifies and groups individual loans according to lenders or purchasers (FNMA) parameters.

Multifamily Seniors Housing Pilot

Credit enhancement for floating rate, multifamily tax-exempt bonds

\section{Guide Announcements}

Expansion of Native American Housing Initiative

Management and Disposition of Acquired Properties

"Full-File" Reporting to Credit Repositories

As of Narch 31, 1996, loan servicers no longer report delinquencies to credit reporting agencies. Instead, they report "full-file" requests electronically.

Changes to Eligibility Requirements for Community Living Group Homes

Data Submitted in REOgrams® (or Datagrams)

Triggers inspections and appointment of pre-approved real estate agents to market/ ' manage property.

Post Foreclosure Property Inspection

Violations of Lead-Based Paint Laws

Nontraditional Mortgage Credit Reports

Custody of Mortgage Documents Related to Reclassified Mortgages 


\section{Lender Letters}

Delinquency Management

Measuring Credit Risk

Discussion of the use of credit scores for individual and collective loan profiles.

Extended Deadline for Using Revised Appraisal Forms

Reproducing Security Instruments and Miscellaneous Mortgage Documents

Fair Lending and the Appraisal Process

Bilingual (Spanish-English) Loan Application Documents

-Residential Loan Application

-Assets and Liabilities

-Requests for Verifications of Deposits and Employment

Standard Cash Transactions and Products

PC-based committing and pricing software with automatic confirmation within 24 hours.

Table 3. Sale and Purchase of a $\$ 100,000$ Home

Comparative closing cost analysis between

traditional and cyber-technology real estate transactions.

(Assumes 100 percent financing.)

\begin{tabular}{|c|c|c|}
\hline & $\begin{array}{c}\text { Closing Costs } \\
\text { Traditional }\end{array}$ & Cyber Tech \\
\hline Real Estate Commission & $\$ 6,000$ & $\$ 3,500^{1}$ \\
\hline Mortgage Application Fee & $\$ 350$ & $\$ 0$ \\
\hline Appraisal Fee & $\$ 300$ & $\$ 25^{2}$ \\
\hline Home Inspection Fee & $\$ 150$ & $\$ 0^{3}$ \\
\hline Loan Origination Fee & $\$ 1,000$ & $\$ 200$ \\
\hline Discount Points & equal & equal \\
\hline Title Insurance and Miscellaneous & $\$ 1,200$ & $\$ 300^{4}$ \\
\hline Mortgage Servicing Fee/Year & $\$ 250$ & $\$ 0$ \\
\hline Mortgage Insurance Premium & equal & equal \\
\hline Transaction Costs & $\$ 9,250^{*}$ & $\$ 4,025$ \\
\hline Time to Close Transaction & $4-6$ weeks & 10 days \\
\hline \multicolumn{3}{|c|}{ *Does not reflect mortgage servicing fee over life of loan, which can be substantially more. } \\
\hline \multicolumn{3}{|c|}{$\begin{array}{l}\text { 'Assumes fees will be reduced to international levels; however, they could be reduced to flat fees } \\
\text { regardless of transaction size. } \\
\text { 'Collateral assessment fee provided by real estate agents.. } \\
{ }^{3} \text { Service merged with collateral assessment fee. } \\
\text { 'Assumes regional and national discount title companies and continued improvement digitizing of } \\
\text { county tax and title records for individual property by parcel number. This system is being imple- } \\
\text { mented in many counties. }\end{array}$} \\
\hline
\end{tabular}




\section{Notes}

${ }^{1}$ Hospitality Franchise System, Inc., with more than 4,C00 Ramada Inn, Days Inn, Super 8 and Howard Johnson hotels, purchased Century 21 Real Estate Corporation that sold $\$ 90$ billion of property in 1994 throughout its 6,000 sales offices.

${ }^{2}$ Sears/Allstate/Coldwell Bankers and Metropolitan Life/Century 21 were perhaps correct in their assessment but wrong in their timing.

${ }^{3}$ Kenneth Nicholson, president of the Appraisal Institute, in a 1996 interview with Cocheo (op. cit.).

${ }^{4}$ This is a function of both technology and an increase in the supply of qualified appraisers.

\section{References and Sources}

Adams, S. "Backlash - Va Real," Forbes Magazine, March 25, 1996, p. 46.

AllRegs ${ }^{\circledR}$ Mortgage Resource Center, Inc., 3460 Washington Drive, Suite 216, Eagan, Minnesota 55122-1338 (to order, call 612-6839705).

Benjamin, John D. and Peter T. Chinloy. "Technologizal Innovation in Real Estate Brokerage," The Journal of Real Estate Research, Vol. 10, No. 1 (1995) 35-44.

Blumenthal, Karen. "Brokers Begin to List Homes On-Line," The Wall Street Journal, January 19, 1996, p. B1

Blumenthal, Karen. "Brokers Offer Financial, Consumer Services," The Wall Street Journal, January 19, 1996, p. B1.

Branner, D. "The Next Boom Industry?," The Communicator Magazine, Vol. 2, No. 2 (1995) 18-19.

Braswell, Michael K. and Stephen L. Poe. "The Residential Real Estate Brokerage Industry: A Proposal for Reform," American Business Law Journal, Vol. 30, No. 2 (1992) 271-334.

Cocheo, S. "USAA: Stealth Bank or 'Bank' of the Future," ABA Banking Journal, Vol. 88, No. 2 (1996) 43-45.
Detweiler, J. and R. Radigan. "ComputerAssisted Real Estate Appraisal: A Tool for the Practicing Appraiser," The Appraisal Journal, Vol. 64, No. 1 (1996) 91-102.

Dun and Bradstreet. Internet Demographics Survey (published by Dun and Bradstreet's Nielsen Media Research and Commerce Net) 1996.

Dunsmore, P. "Banking With Ease," Times Record News, March 5, 1996, p. 1B, Wichita Falls, Texas.

Fannie Mae's Market Line Digest, Fannie Mae Fulfillment Center, 9060 Junction Drive, Suite 12, Anapolis Junction, Maryland 20701, December 1995 (to order, call 800-471-5554).

Fannie Mae's Market Line Digest, Single Family Marketing, 3900 Wisconsin Ave. NW, Washington, DC 20016-2897, January 1996.

Fletcher, June and David Crook. "A Guide to Selected Real Estate Sites on the Web," The Wall Street Journal, January 19, 1996, p. B8.

Fletcher, June. "How to Shop for a Home on the Internet," The Wall Street Journal, January 19,1996, p. B8.

Ghosh, Chinmoy, Randall S. Guttery and C. F. Sirmans. "The Effects of the Real Estate Crisis on Institutional Stock Prices," working paper, University of Connecticut, 1996.

Gilon, P. and C. Cardenas. "Appraisers and Cyberspace: An Introduction to the Internet," The Appraisal Journal, Vol. 63, No. 4, (1995) 469-81.

Grogan, Gwin. "Home on the Internet," Dallas Business Journal, February 9-15, 1996, p. 22.

"If You Don't Like How Things Are ...," The Communicator Magazine, Vol. 2, No. 3 (1995) p. 10.

LaDuca, Angelo L. "Change Is in the Air," Appraiser-Gram, Vol. 26, No. 1, (1996) p. 1.

Lunt, P. "Welcome to 'sfnb.com' The Paradigm Just Shifted," ABA Banking Journal, Vol. 87, No. 2, (1996) 40-47.

Manning, Chris. RAL Information Services, Carmel, Indiana (800-766-2366 ext. 833).

Millman, J., Forbes Magazine, Patel, Inc., August 4, 1995, p. 88. 
O'Donnell, James. "Appraisers Capture Data Online," Real Estate Valuation Magazine, Vol. 45, Fall 1995, p. 10

O'Rourke, Ann. "Surfing the Net," Real Estate Valuation Magazine, Vol. 45, Fall 1995, pp. 4-11.

Rampy, J. "Trading Places," Dallas Business Journal, October 27, 1995, p. B1.

Rayburn, W. and D. Tosh. "Artificial Intelligence: The Future of Appraising," The Appraisal Journal, Vol. 63, No. 4, (1995) 429-35.

Regan, Cheryl. "Freddie Mac Enhances Loan Prospector," Real Estate Valuation Magazine, Vol. 46, Winter 1996, p. 34. (Ms. Regan is media relations manager for Freddie Mac at 800-424-5401.)

Rosen, M. "Virtual Realty-Real Estate Agents Face Extinction in an Information-Rich Century 21," Dallas Observer, January 18, 1996, p. 6 .
Schwartz, P. and D. Yates. "Information on Location," Real Estate Valuation Magazine, Vol. 45, Fall 1995, p. 7.

Software for Real Estate Professionals, 1996, 7423 Picardy Ave., Suite F, Baton Rouge, Louisiana 70803-4362.

Warren, S. "If Texas Appraisers Suffer Feelings of Low Self-Worth, They Have Cause," The Wall Street Journal, March 20, 1996, p. B14.

Worzala, E., Margarita Lenk and Ana Silva. "An Exploration of Neural Networks and Its Application to Real Estate Valuation," The Journal of Real Estate Research, Vol. 10, No. 2 (1995) 185-202. 


\section{Reprint Policy}

The Real Estate Center has no objection to others reprinting all or part of this publication providing these guidelines are followed:

- The author is given full credit,

- The Real Estate Center is cited as the original publisher of this material,

- Reprints are not resold for profit,

- No substantive additions or deletions are made in the copy and

- Two copies of the reprint are sent to the Senior Editor:

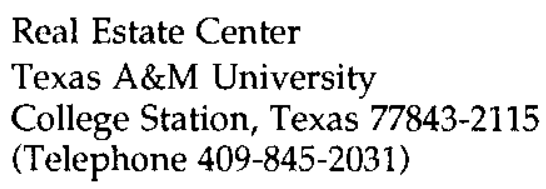

Views expressed herein are those of the authors. Publication of these views does not imply endorsement by the Real Estate Center, the L. Lowry Mays College of Business Administration and Graduate School of Business or Texas A\&M University.

This publication was funded by appropriations to the Real Estate Center by the Texas Legislature.

\section{Additional Copies}

Requests for additional copies of this publication should be directed to the Publications Room at the address listed above.

\section{Quantity Discounts}

Discounts may be granted for quantity orders. Requests for such discounts should be made in writing to the Director, Real Estate Center. Such requests should state the quantity desired, purpose for which the item will be used and any other pertinent information that may assist in price determination. Instructors with special projects or unique requirements for multiple copies may receive special consideration. Such requests should be submitted in writing on college or university letterhead to the Center director.

\section{Other Topics Available}

Publications of the Real Estate Center are designed to meet the needs of many audiences, including the real estate industry, instructors and researchers and the general public. Several hundred publications are available from the Center on a wide range of topics. A copy of the Center catalog is available from the Center Publications Room and on the Center's Internet site at http:// RECenter.tamu.edu. 


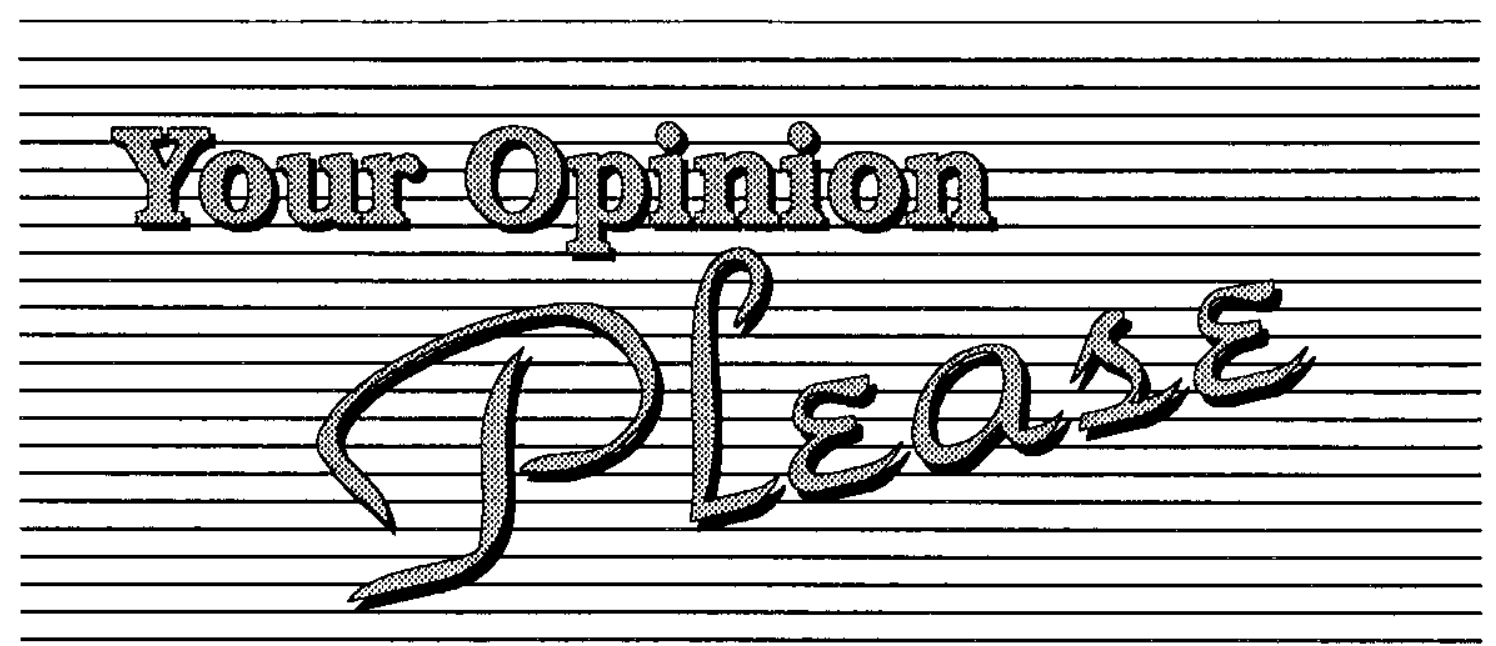

Thank you for ordering this publication from the Real Estate Center. To better serve you, we would appreciate your suggestions. Please take a few minutes to answer the following questions and return this postage-paid sheet to the Center.

1. Please evaluate each characteristic of this publication:

$\begin{array}{lccccc} & \text { Excellent } & \text { Good } & \text { Fair } & \text { Poor } & \text { No Opinion } \\ \text { overall content } & \square & \square & \square & \square & \square \\ \text { technical detail } & \square & \square & \square & \square & \square \\ \text { clarity } & \square & \square & \square & \square & \square \\ \text { organization } & \square & \square & \square & \square & \square\end{array}$

2. To what degree did this publication meet your needs?

$\begin{array}{lllllll}\text { very useful } & 5 & 4 & 3 & 2 & 1 & \text { not useful at all }\end{array}$

3. How did you hear about this publication?

4. What magazines or periodicals do you read most regularly to stay informed about real estate topics?

a)

c)

5. What other topics would you like to know about? b)

d)

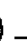

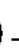

6. What is your principal occupation?

7. What real estate license do you hold? $\square$ broker $\square$ salesperson $\square$ none COMMENTS:

Check to receive the Center's FREE catalog listing more than 300 publications and computer software.

Name

Address

City Zip 
NO POSTAGE NECESSARY

IF MAILED

IN THE

UNITED STATES

\section{BUSINESS REPLY MAIL}

FIRST CLASS PERMIT NO. 148 COLLEGE STATION TX 77843

POSTAGE WLL BE PAID BY ADDRESSEE

REAL ESTATE CENTER

TEXAS A\&M UNIVERSITY

COLLEGE STATION TX 77843-9990

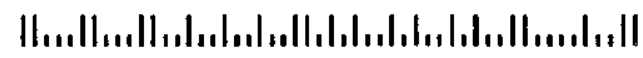

No. 1143 

Date Due

A charge is made for overdue books

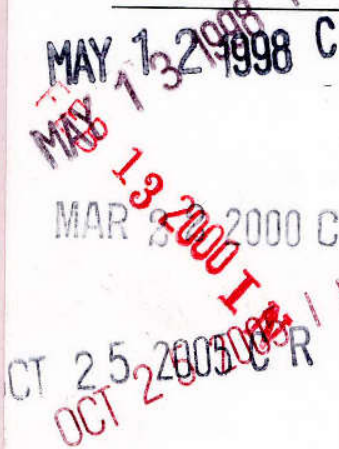

(Form 14- 10/95) 